\title{
Hyperthermia for Oral Cancer
}

\author{
IWAI TOHNAI* \\ Department of Oral and Maxillofacial Surgery, Yokohama City University Graduate School of Medicine, 3-9 \\ Fukuura, Kanazawa-ku, Yokohama 236-0004, Japan
}

Abstract: Dysfunctions and cosmetic disturbance after surgery for oral cancer are major problem. I focused hyperthermia as non-invasive therapy for oral cancer. Magnetic induction interstitial hyperthermia using ferromagnetic implant needle (Implant heating system: IHS) has been developed, and the antitumor effectiveness was studied experimentally and clinically for tongue cancer. The effectiveness of hyperthermia tended to extend gradually toward the peripheral side of the tongue tumor inoculated VX7. Eight patients with primary cancer of the oral cavity were treated using hyperthermia combined with chemotherapy. As a result, the thermal distribution was good, and complete response was observed in all patients.

The antitumor effectiveness of interstitial hyperthermia using magnetic liposomes was studied experimentally. The primary tongue tumor was disappeared due to good thermal distribution. Magnetic liposomes were delivered selectively to the cervical lymph node metastasis. Then, necrosis and apoptosis were observed in the cervical lymph node metastasis under alternating magnetic field. Ferucarbotran of existing drugs was heated under alternating magnetic field. Combination of cisplatin with ferucarbotran under alternating magnetic field induced apoptosis of cancer cells more effectively than cisplatin alone with significant differences. A new anti-cancer agent for magnet-guided delivery with anti-cancer activity ( $\mathrm{Fe}$ (Salen)) was studied experimentally in terms of antitumor effectiveness. Fe (Salen) alone inhibited the growth of tongue tumor. The heat was confirmed in Fe (Salen) under alternating magnetic field, and tongue tumor was disappeared with interstitial hyperthermia using Fe (Salen).

The combined therapy with superselective intra-arterial chemoradiotherapy and RF hyperthermia was effective therapy for advanced oral cancer with cervical lymph node metastasis (N3). This therapy is promising as a new strategy of non-invasive therapy for advanced oral cancer.

Key Words: oral cancer, hyperthermia, magnetic induction interstitial hyperthermia, magnetic particle, superselective intra-arterial chemoradiotherapy

\section{1. 緒言}

口腔癌は舌癌, 上顎歯肉癌, 下顎歯肉癌, 煩粘膜癌, 口底癌, 硬口蓋癌の 6 部位の癌であるが, 現在 の標準治療は手術である。しかしながら, 術後の機能障害（構音障害，咀嚼障害，嚥下障害）を生じる

Received 12 April, 2017, Accepted 10 October, 2017. *Corresponding author: Tel, +81-45-787-2659; Fax, +81-45-785-8438;

e-mail, tohnai@yokohama-cu.ac.jp

doi: 10.3191 /thermalmed.33.103

o2017 Japanese Society for Thermal Medicine 
Thermal Med, 33〔4]: 103-115, 2017.

ことは避けられず, 特に, 進行癌になるとその障害は大きくQOL が著しく低下する，さらに，機能障 害のみならず, 術後に口腔顎顔面領域に傷跡がつくという審美的（整容的）障害が生じることも口腔癌 治療の大きな特徵であり, これが胃癌, 肺癌などの他領域の癌治療との決定的な違いである。よって, 口腔癌を扱う我々にはこのような進行口腔癌に対して機能温存はもちろんのこと, 審美的障害も生じな い治療が強く求められる。言い換えれば非侵襲的治療（臓器温存治療）が求められる代表的部位の癌で あり，その治療戦略の一つとしてハイパーサーミアに着目し研究を開始した.

ハイパーサーミアに関しての研究は heat shock protein (HSP), 温熱耐性, 局所免疫などに関してin vitro, in vivoに扔いて行ったが1-11), 今回は口腔癌に対する磁場誘導組織内加温法の基礎と臨床, 超選 択的動注化学放射線療法と $\mathrm{RF}$ 誘電外部加温法を用いたハイパーサーミアとの併用療法を中心に述べ る.

\section{2. 磁場誘導組織加温法}

\section{1. 磁性体針を用いた磁場誘導組織内加温法}

口腔癌の原発巣（舌など）へのハイパーサーミアは, 従来の RF 誘電加温装置などの外部加温法では アプリケーターの固定が不可能なため, 原発巣への加温は解剖学的に困難な部位とされていた。 そこで, 脳腫瘍に対する磁性体を用いた磁場誘導組織内加温法（Implant heating system: IHS）が考案されたの で12,13)，口腔癌への応用の可能性を検討した。 IHS の原理は磁性体が高周波磁場下で発生する渦電流損 を利用したものであり, あらかじめ腫瘍内に発熱磁性体を挿入（刺入）し，外部より磁性体の長軸方向 と平行に高周波磁場を印可することにより磁性体が発熱する。この発熱装置は磁性体と高周波磁場を作 成する誘導コイル，高周波発信器より成る（Fig. 1A）。口腔癌に対するIHS の口腔腫瘍効果を実験的, 臨床的に検討した。

\subsection{1. 実験}

実験用の磁性体は Fe-Pt 合金 (Fe: 73\%, Pt: 27\%) であり, 刺入しやすいように針状（磁性体針）になっ ており, 直径 $1.8 \mathrm{~mm}$, 長さ $15 \mathrm{~mm}$ でキュリー温度は $68^{\circ} \mathrm{C}$ である（Fig. 1B）。誘導コイルは直径 $13 \mathrm{~cm}$ であり, 高周波発振器は出力 $200 \mathrm{~W}$, 周波数 $500 \mathrm{kHz}$ を有し, 磁場はコイルの中心で $16.7 \mathrm{Oe}$ の強さで ある。

実験動物は体重 2 2.5 kg の雄系日本白色家兔で腫瘍細胞は家鬼に可植性であるVX7 腫瘍を使用し, 舌に移植 12〜16 日後，腫瘍の直径が 10〜15 mmに達した時点に実験を開始した。

温度分布については，磁性体針を 1 本刺入し，舌腫瘍内の温度分布を加温 15 分後の磁性体針㧍よび 磁性体針から $2.5 \mathrm{~mm}$ 間隔で銅一コンスタンタン熱電対（Bailey 社使用）を用いて測温した。その結果, 磁性体針自身は $63.1^{\circ} \mathrm{C}, 5 \mathrm{~mm}$ 離れた部位で $43.1^{\circ} \mathrm{C}$ であった（Fig. 1C)。病理組織学的検討のために, 加温後に腫瘍を残存させるため磁性体針は舌腫瘍中心部に 1 本のみ刺入とし, 磁性体針をコイル内で磁 束と平行になるように固定し 30 分間 1 回加温した。加温直後は磁性体針を中心に壊死に陥っているが, 境界は不明瞭であった（Fig. 1 D a ) . 3 日後には壊死部がさらに広がり，中枢側には狭く抹消側には広が る形態を示した (Fig. 1D b, 白矢印)，5日後には壊死領域の融解吸収に伴う縮小とその周辺部の腫瘍細 胞の増殖が特に中枢側に認められた（Fig. 1D c, 白矢印）。また，腫瘍の中枢側の正常組織に腫瘍細胞 は結節状に増殖し浸潤していた（Fig. 1Dd）。これらのことょり，舌腫瘍の中枢側は血流が豊富なため に温熱効果が弱いことが推測された。抗腫瘍効果の検討のために, 舌腫瘍内に辺縁より $5 \mathrm{~mm}$ 以内に正 三角形に磁性体針を 3 本刺入し, 45 分間の 1 回加温を行った。腫瘍は加温後 2 週目で著明に減少し壊 死脱落による舌の欠損が認められたが，対照群では舌全体に及ぶ腫瘍の増殖が認められた ${ }^{14,15)}$ 。このこ 

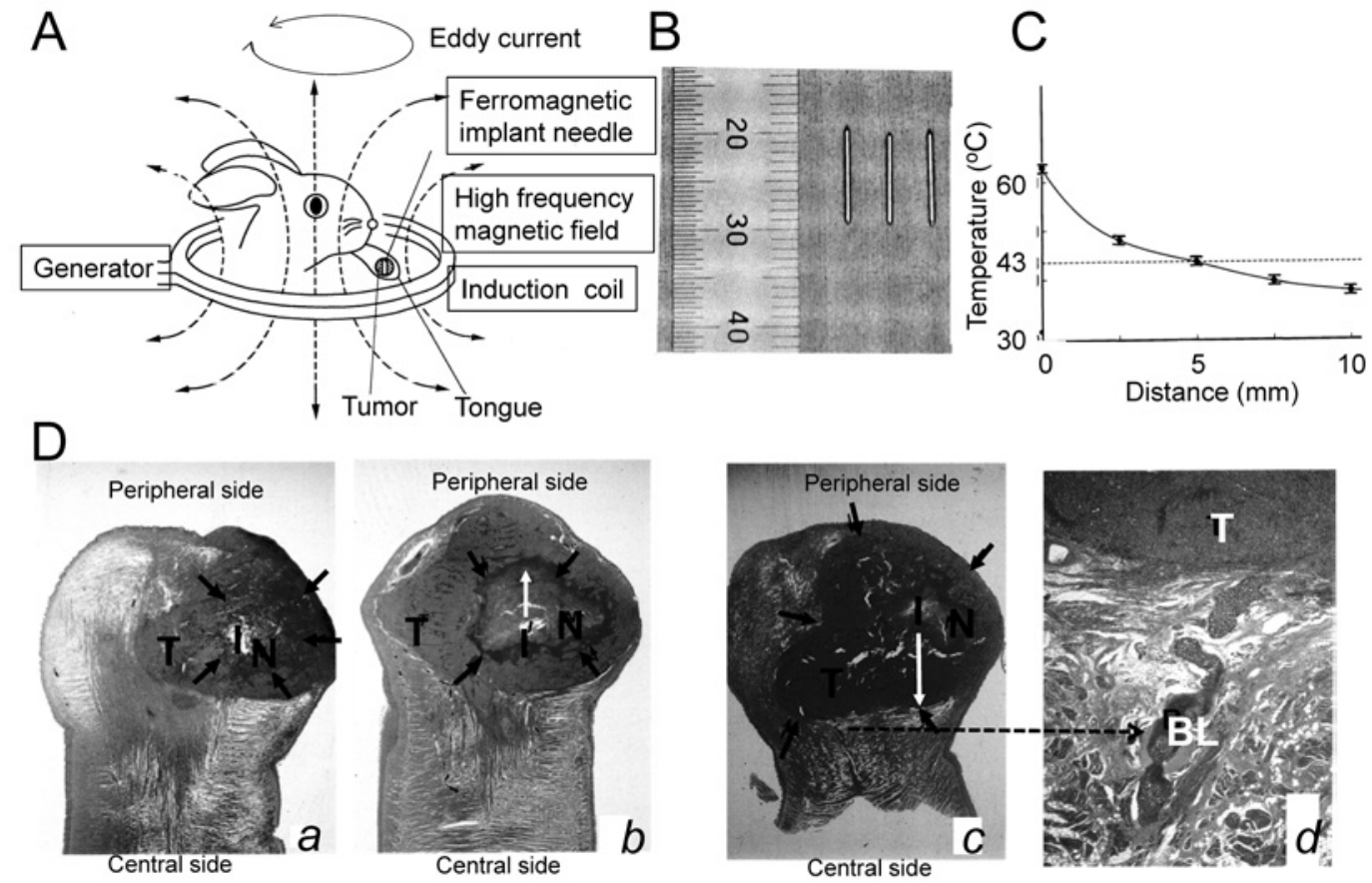

Fig. 1. A: Scheme of implant heating system (IHS). IHS is composed of three compartments; Implant needle, induction coil and generator yield magnetic power of 16.7 Oe with frequency of $500 \mathrm{kHz}$. B: Implant needles (Fe-Pt implants with low Curie point). C: Temperatures around an implant. The temperature of an implant was $63.1^{\circ} \mathrm{C}$ and $5 \mathrm{~mm}$ apart from the implant was $43.1^{\circ} \mathrm{C}$. D: Pathological findings [HE stain] after hyperthermia using IHS in rabbit tongue tumor (VX7). $\boldsymbol{a}$ : Immediately after hyperthermia. Heated tissue showed necrosis around the implant. The shape of necrosis was irregular and indistinct. $\boldsymbol{b}: 3$ days after hyperthermia. Distinct necrosis enlarged toward the peripheral part. $c: 5$ days after hyperthermia. Necrotic area decreased and tumor regrowth took place at the central part. $d$ : Blood vessel in intact tissue was occluded by tumor cells. I: Ferromagnetic implant needle, T: Tumor, N: Necrosis, BL: Blood vessel. A-C: Adapted from Goto et al. ${ }^{14)}$, D: Adapted from Goto et al. ${ }^{15)}$.

\subsection{2. 陁床}

臨床用の磁性体は Fe-Pt 合金 (Fe: 73\%, Pt: 27\%) であり, 刺入しやすいように針状（磁性体針）になっ ており，直径 $1.8 \mathrm{~mm}$, 長さ $15,20,25 \mathrm{~mm}$ でキュリー温度は実験用と同様に $68^{\circ} \mathrm{C}$ である（Fig. $2 \mathrm{~A} ）$. 磁場発生装置は最大出力 $2.5 \mathrm{~kW}$, 周波数 $250 \mathrm{kHz}$ であり, 内径 $30 \mathrm{~cm}$ の円形誘導コイルの中心で最大 $16 \mathrm{Oe}$ の磁場が得られる (Fig. 2B). 磁性体針の加温状態は針の辺縁からの距離を $5 \mathrm{~mm}$ 間隔で測定した. 磁性体針のキュリー温度は $68^{\circ} \mathrm{C}$ であるが，腫瘍内においては最高 $60^{\circ} \mathrm{C}$ までしか上昇せず， $5 \mathrm{~mm}$ 離れ た部位では $43.5^{\circ} \mathrm{C}, 10 \mathrm{~mm}$ で $39.8^{\circ} \mathrm{C}$ であった（Fig. 2C). 名古屋大学の倫理委員会の承認を得て口腔癌 の術前治療として IHS の組織内温熱療法と化学療法の併用療法を行い検討した，針と針との間隔は $10 \mathrm{~mm}$ であれば腫瘍内温度は $43^{\circ} \mathrm{C}$ 以上になり，腫瘍の大きさに合わせ腫瘍内に複数の磁性体針を磁力 線の方向に平行（誘導コイルに垂直となる）に刺入し，3６回の温熱療法（45分/回/週）と抗癌剤の シスプラチン（CDDP） $200 \mathrm{mg}$, ペプロマイシン（PEP） $60 \mathrm{mg}$ の投与を 5 週間で行った。 その後, 手 
術を行ったが切除病理所見では腫瘍細胞はみられず pCR（pathologically complete response）が得られ た ${ }^{16,17)}$ ．温熱療法中の磁性体針と腫瘍内温度を経時的にみると加温開始 5 分以内には磁性体針は $60^{\circ} \mathrm{C} に$ なり, 腫瘍内温度は 10 分以内に $43^{\circ} \mathrm{C}$ に昇し, その後安定した温度が継続していた。同様の治療を 8 例の口腔癌患者に対して行ったが切除病理学的検討で全ての症例で腫瘍細胞は認められなかった18,19). また，手術拒否の舌癌（T2N0M0）患者（Fig. 2Da）に対して同様に 5 本の磁性体針を刺入し（Fig. $2 \mathrm{D} b)$ ）, IHS の組織内温熱療法と化学療法の併用療法のみで CR が得られ (Figs. 2D $c$ and $2 \mathrm{D} d$ ) ${ }^{20)}$, さらに, 悪性線維性組織球腫に対しても有用性が確認された211.

A

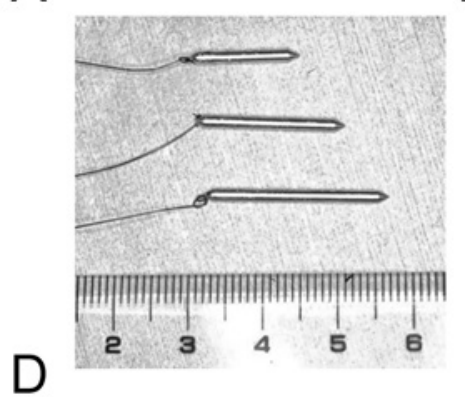

B
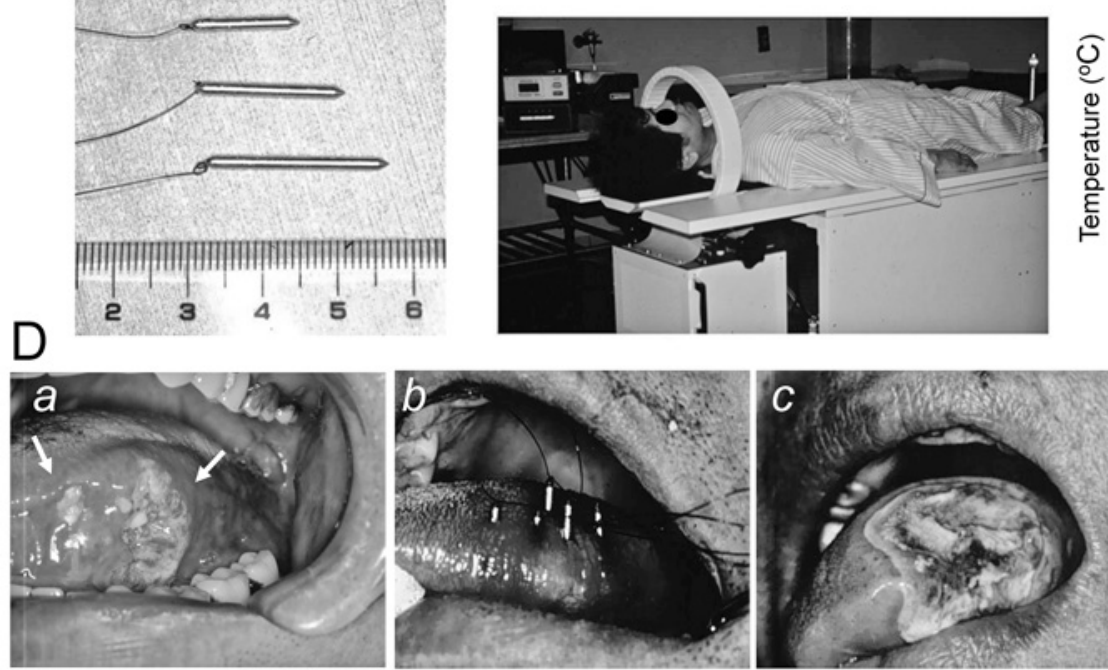

C
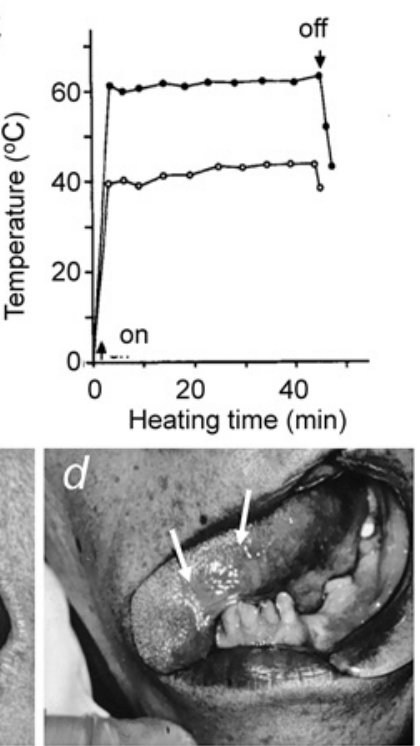

Fig. 2. Implant heating system (IHS) in clinical use. A: Implant needles ( 3 different size). B: Induction coil: $30 \mathrm{~cm}$ in diameter, Generator: $250 \mathrm{kHz}, 16$ Oe. C: Thermal distribution. D: Tongue cancer (T2N0M0). $\boldsymbol{a}$ : Before treatment. $\boldsymbol{b}$ : Insertion of 5 implant needles. $\boldsymbol{c}: 2$ days after thermochemotherapy without radiotherapy. $\boldsymbol{d}$ : 1 year after thermochemotherapy without surgery. A-C: Adapted from Tohnai et al. ${ }^{16-20)}$, D: Adapted from Tohnai et al. ${ }^{21}$.

\section{3. 磁性微粒子を用いた磁場誘導組織内加温法}

IHS は磁性体針が絶えず交流磁場に対して垂直方向に位置すれば発熱し, 加温効果も高いが, 磁性体 針が磁場に対して垂直を保てなければ加温状態が悪くなることが大きな問題点であった。そこで，磁性 体が交流磁場の方向性の影響を受けないような磁性微粒子を用いた組織内温熱療法の抗腫瘍効果を検討 した.

\subsection{Magnetic liposomes を用いた検討}

\subsection{1. 腫瘍原発巣に対する検討}

磁性微粒子である magnetic cationic liposomes（MCLs）を用いて，原発巣に対して実験的に検討した。 MCLs は核となるマグネタイト $\left(\mathrm{Fe}_{3} \mathrm{O}_{4}\right.$ ：大きさ $\left.10 \mathrm{~nm}\right)$ をフォスファチジルコリンとフォスファチジ ルエタノールアミンと塩化ジドデシル -D-グルタミン酸塩を $2: 2: 1$ で組成し, 調整したリン脂質膜で 被覆することにより得た中性電荷リポソームである（Fig. 3A）。実験動物は家兔 VX7 腫瘍を使用し, 
移植舌腫瘍内に MCLs を $3.3 \mathrm{mg}$ 注入し, 30 分 1 回加温の抗腫瘍効果を観察した。なお, 磁場発生装置 は内径 $7 \mathrm{~cm}$ の誘導コイルを有する交番磁場発生装置であり, $5 \mathrm{~kW}, 118 \mathrm{kHz}$ 下で $384 \mathrm{Oe}$ の磁場を発生 する (Fig. 3B)，腫瘍内の温度は磁場照射後 3 分で $43^{\circ} \mathrm{C}$ に達し，その後の温度は極めて安定していた (Fig. 3C)，移植舌腫瘍が $10 \mathrm{~mm}$ の大きさになった時点で実験を開始し（Fig. 3D），18 日目には腫瘍は 肉眼的, 組織学的に消失した (Figs. $3 \mathrm{E}$ and $3 \mathrm{~F}$ ) が, 対照群 (非加温) では腫瘍は増大し (Figs. $3 \mathrm{G}$ and 3H），12 日目まですべての家鬼は死亡した。腫瘍の大きさが $10 \mathrm{~mm}$ になった時点を 1 とした腫瘍増殖 曲線を Fig. 3I に示すが, 対照群は 12 日目では約 5.5 倍となり, その時点で全ての家鬼は死亡した。加 温した群では 18 日目には腫瘍は完全に消失した22).

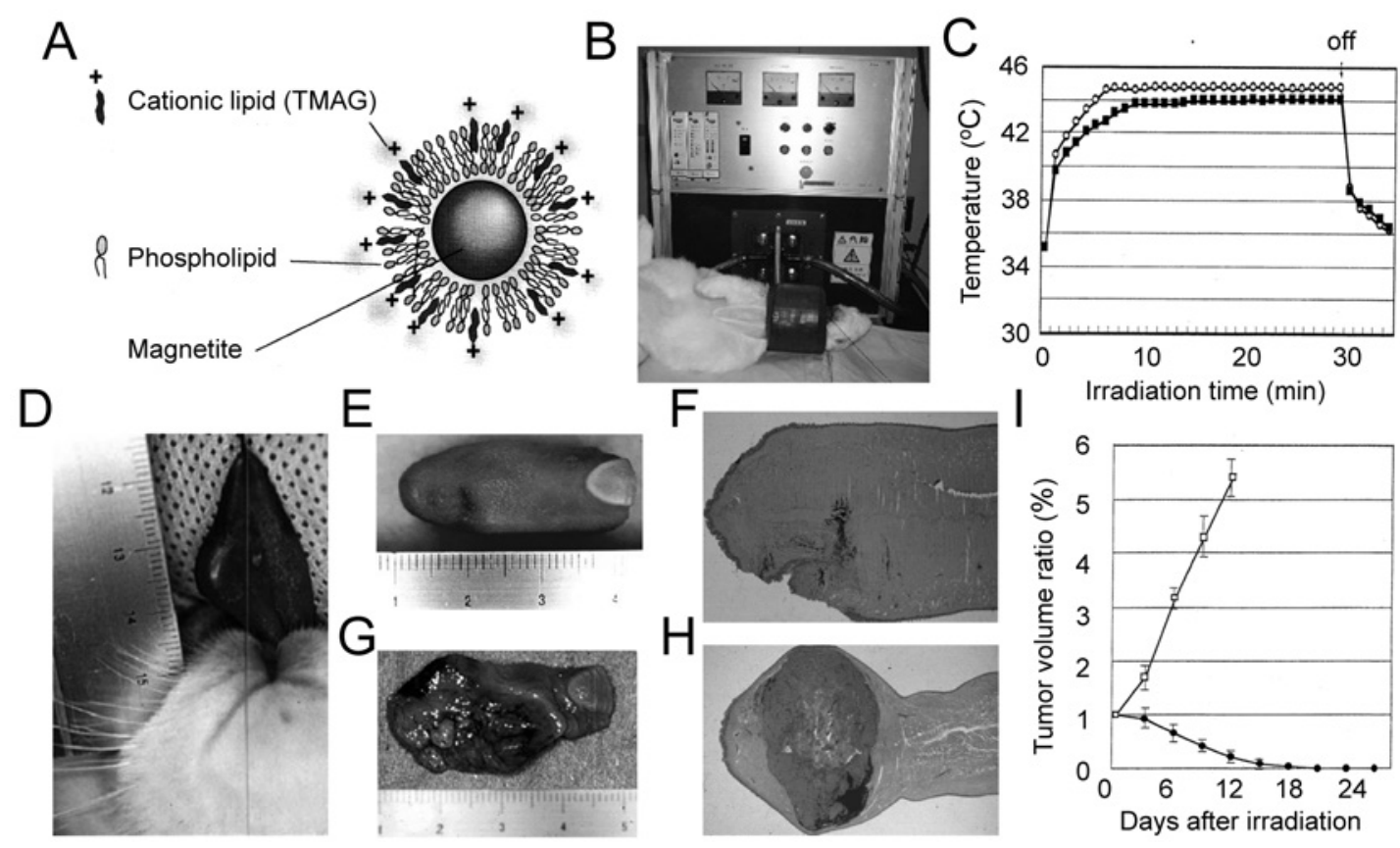

Fig. 3. A: Schematic representation of magnetic cationic liposome (MCL). Cationic lipid TMAG: N-(cytrimethylammonioacetyl) didodecyl-D-glutamate chloride molecules. Phospholipid DPPC: Dilauroylphosphatidylcholine molecules. Phospholipid DPPE: Dioleoylphosphatidylethanolamine molecules. B: Induction coil $(7 \mathrm{~cm})$ and generator yield magnetic power of 384 Oe with frequency of $5 \mathrm{~kW}$. C: Temperature in the tumor during irradiation. The temperature in the center of the VX-7 tumor increased rapidly and reached 43 centigrade $3 \mathrm{~min}$ after starting irradiation. In contrast, it took 5 min until the tumor margin was heated to $43^{\circ} \mathrm{C}$. The temperature was maintained during irradiation. Data points are the means of 3 independent experiments. $\bigcirc$, center of the tumor. $\mathbf{\square}$, tumor margin. D: Rabbit tongue tumor. E: 18 days after hyperthermia. F: Pathological finding in 18 days after hyperthermia. G: Control; 12 days after tumor mass had grown to a size of about $10 \times 10 \mathrm{~mm}$. H: Pathological finding of control. I: Time course of tumor growth after MCL injection. In group I rabbits with irradiation, the tumor in each rabbit almost completely regressed. In contrast, in group II, the tumor volume of all rabbits increased gradually, with no evidence of regression. Data points are the means of 4 independent experiments. , hyperthermia group. $\square$, control group. Adapted from Matsuno et al. ${ }^{22}$. 


\subsection{2. 頸部リンパ節転移巣に対する検討}

磁性微粒子を用いて移植舌腫瘍内に注入さ れた磁性微粒子をリンパ行性に頸部リンパ節 転移巣に移行させ, 次いで頸部局所のみに高 周波磁場を照射し, 頸部リンパ節転移巣に対 する選択的磁場誘導組織内温熱療法の有用性 の検討を行った. 磁性微粒子は magnetic liposomes（MLs）を用いたが，核となるマ グネタイト $\left(\mathrm{Fe}_{3} \mathrm{O}_{4}\right)$ をフォスファチジルコ リンとフォスファチジルエタノールアミンと を $2: 1$ で組成し調整したリン脂質膜で被覆 することにより得た中性電荷リポソームであ る. 家鬼舌に VX7 腫瘍を移植後 20 日目には 頸部リンパ節転移するため, この時点で, 舌 腫瘍に $15 \mathrm{mg}$ の MLs 溶液を局注し, その後, 24 時間後にリンパ節内での MCLs を肉眼的, 病理組織学的に確認（Figs. 4A and 4B） L, 頸部のみに高周波磁場を 40 分照射した。加 温開始から 5 分で頸部リンパ節転移巣の温 度は $42.5^{\circ} \mathrm{C}$ に達し, 以後その温度は維持さ れた (Fig. 4C). 無処置群 (Group I), MLs の舌への局注のみ (Group II), 舌に MLsを 局注し頸部に高周波磁場を照射（Group III） 群に分け検討した，頸部リンパ節転移巣の 壞死面積率はそれぞれ $19.6 \%, 20.4 \%$, $58.0 \%$ であり, また, アポトーシス陽性細胞
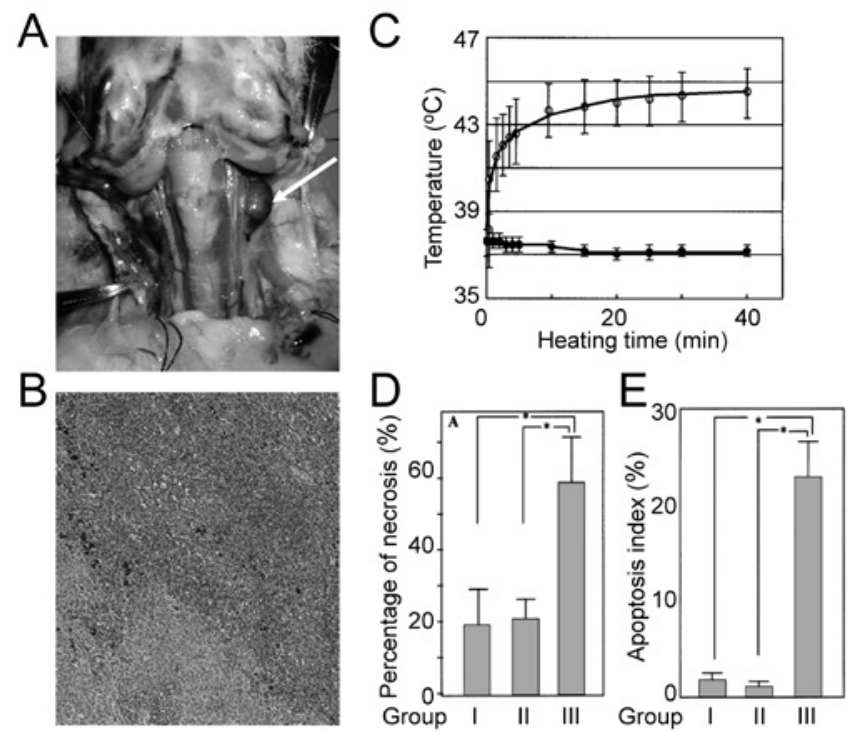

Fig. 4. A: Deep cervical lymph node and afferent lymphatics were stained black with magnetic liposomes (MLs). B: Light microscopic section of the deep cervical lymph node (HE stain). The left corner wasoccupied by a metastatic tumor. MLs were localized in the marginal area of tumor. C: Temperature increase in the deep cervical lymph node and rectum of group III animals during magnetic field irradiation. Open circle, in lymph node; closed circle, in rectum. Data points and bars are means and SDs of 5 independent experiments. Assessment of necrosis (D) and apoptosis (E) in deep cervical lymph nodes. Asterisk indicates a significant difference. ${ }^{*}: p<0.05$. Adapted from Hamaguchi et al. ${ }^{23)}$.

数の割合はそれぞれ $1.67 \%, 1.42 \%, 22.9 \%$ であり, Group III 群において有意に高值であった（Figs. $4 \mathrm{D}$ and $4 \mathrm{E})$ ．以上より，口腔癌原発巣への磁性微粒子の注入で頸部リンパ節転移巣への磁性微粒子の移 行を認め, さらに頸部への磁場照射の付加で頸部リンパ節転移にも抗腫瘍効果が期待できた23).

\section{2. フェルカルボトランを用いた検討}

現存の薬剤の中で, 温熱療法での磁性微粒子になり得るものとしてフェルカルボトラン（リゾビス

ト $\left.{ }^{\circledR}\right)$ に着目した。フェルカルボトランは主として肝臓のクッパー細胞に取り达まれることにより MRI 画像上, クッパー細胞を有さない肝臓の悪性腫瘍とのコントラストを向上させる肝特異性 MRI 造影剂 として応用されている. 電流 $250 \mathrm{~A}$, 周波数 $308 \mathrm{kHz}$, 誘導コイルの直径は $4 \mathrm{~cm}$ での状況下, フェルカ ルボトラン濃度 $10 \mathrm{mM}$ で約 $42.5^{\circ} \mathrm{C}$ の温度上昇が確認できた。 ヒト由来扁平上皮癌細胞（HSC-3 細胞, OSC-19細胞）に拈けるCDDP と交流磁場下でのフェルカルボトラン温熱併用によるアポトーシス誘導 の増強作用を, フローサイトメトリーを用いて検討したが, CDDPに交流磁場下でのフェルカルボト ランによる温熱を併用することにより，CDDPのアポトーシス誘導作用が明らかに増強されることが 確認できた24). 


\section{3. 新规磁性微粒子の応用}

磁性体単体で抗腫瘍効果を持つ新規磁性体有機化合物（ $\mu$-oxo N,N’-bis (salicylidene) ethylenediamine iron（以下 Fe（Salen））が同定されたが，VX2 腫瘍を家兔舌に移植し，この磁性微粒子の抗腫瘍効果 についても検討した，無処置群 (cont群) (Fig. 5Aa), Fe (Salen) 静脈投与した群 (5 mg/kg) (i.v. 群) (Fig. $5 \mathrm{Ab}), \mathrm{Fe}$ (Salen) 投与 $(5 \mathrm{mg} / \mathrm{kg})$ し電磁石による局所集積を行った群 (i.v. + EM (electromagnet) 群) (Fig. $5 \mathrm{Ac}), \mathrm{Fe}$ (Salen) 連日投与（5 mg/kg） し電磁石による局所集積した後に交流磁場によるハイ パーサーミアを行った群（i.v. + EM + AMF（alternating magnetic field）群) (Fig. 5Ad）の 4 群で検討 した。なお， Fe (Salen) の投与は耳静脈から行い, 交流磁場印加群は交流磁場下で 1 時間温熱刺激した。 また, 電流 $250 \mathrm{~A}$, 周波数 $380 \mathrm{kHz}$ 誘導コイルの直径は $6.7 \mathrm{~cm}$ の状況下での交流磁場下で行った. cont 群（Fig. 5Ae）と比較して, Fe（Salen）静脈投与群（Fig. 5Af）， Fe（Salen）投与し電磁石による局所 集積を行った群（Fig. $5 \mathrm{Ag}$ )，㧍よび Fe（Salen）静脈投与し電磁石による局所集積した後に交流磁場に よるハイパーサーミアを行った群（Fig. $5 \mathrm{Ah}$ ）では明らかな腫瘍縮小効果を認めた，腫瘍増殖曲線を Fig. 5B に示すが, 特に, ハイパーサーミアを行った群では, 腫瘍の有意な抗腫瘍効果を認めた。 それ ぞれの群の病理組織学的所見においは, cont群（Fig. 5Ca）に比べて i.v. 群, i.v. + EM 群, i.v. + EM+ $\mathrm{AM}$ 群になるにつれ腫瘍は減少しており，また壊死率をみると i.v. + EM 群, i.v. + EM+ AMF 群は cont 群に比べて有意に壊死率が高くなっていた（Fig. 5D) ${ }^{25}$. Fe（Salen）単独でも抗腫瘍効果を示した

A

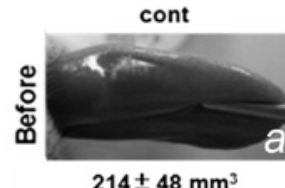

$214 \pm 48 \mathrm{~mm}^{3}$
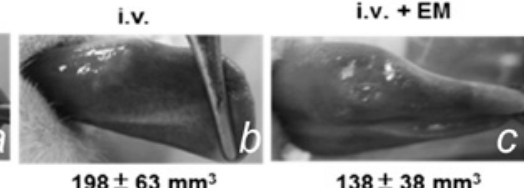

$\bigcap^{1 \text { week }}$ i.v. + EM + AMF

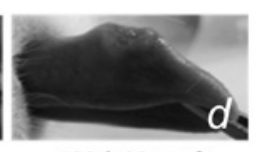

$188 \pm 68 \mathrm{~mm}^{3}$

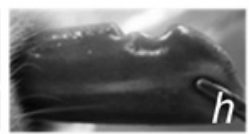

$50 \pm 32 \mathrm{~mm}^{3}$

D

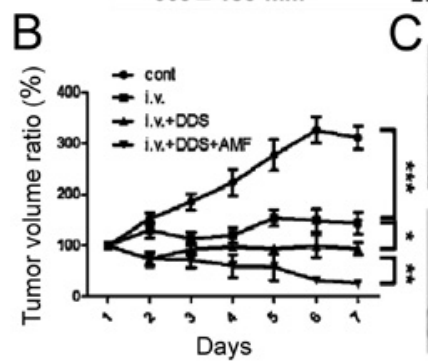

C
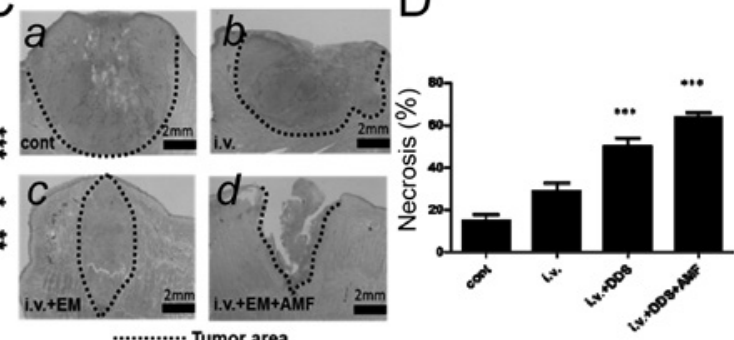

Fig. 5. A: Representative photos of rabbit tongue tumors in each group before (upper: $a-d$ ) and after (lower: $e$-h) treatment. Mean tumor volume value $\left(\mathrm{mm}^{3}\right)$ of each group is also shown. Control (cont), intravenous injection of Fe (Salen) nanoparticles (i.v.), Fe (Salen) nanoparticle injection and electromagnet application (i.v. + DDS), and Fe (Salen) nanoparticle injection, electromagnet application, and AMF exposure (i.v. $+\mathrm{DDS}+\mathrm{AMF})$. B: Changes in tumor volume ratio for 7 days. $(\mathrm{n}=6, *: p<0.05$, **: $\left.p<0.01,{ }^{* * *}: p<0.001\right)$. C: Representative histological photo by HE staining at day 7 (upper: $a$ and $b$ ). Broken lines indicate tumor areas. Calibration bar: $2 \mathrm{~mm}$. Quantification of necrotic area by HE staining (lower: $c$ and $d$ ). D: Necrosis $(\%) . \mathrm{n}=4,{ }^{* * *}: p<0.001$. A-C: Adapted from Sato et al. ${ }^{25}$. 
が，さらに，交流磁場下において Fe（Salen）を発熱させることで抗腫瘍効果のさらなる増強を認め, 興味ある結果が得られた。

\section{4. 超選択的動注化学放射線療法とハイパーサーミアとの併用療法}

4.1. 頸部リンパ節転移 (N3) に対する超選択的動注化学放射線療法とハイパーサーミアの併用療法 (術 前治療)

進展口腔癌に対する化学放射線療法とハイパーサーミアの併用療法の報告はあるが26-28), 頸部リンパ 節転移の制御は困難とされている。中でも転移の大きい $\mathrm{N} 3$ 症例は極めて困難とされており，また，そ の化学療法のほとんどが静脈投与での報告であった ${ }^{29}$. そこで, N3 リンパ節転移に対して, 浅側頭動 脈や後頭動脈より逆行性に腫瘍栄養動脈に超選択的にカテーテルを挿入する新しい逆行性超選択的動注 法（Figs. 6A and 6B）を用いた化学療法 ${ }^{30-32}$ ) と放射線療法とハイパーサーミアとの併用療法を術前治療 として試みた。治療内容は逆行性超選択的動注化学放射線療法（Retrograde superselective intra-arterial chemoradiotherapy: IA-CRT） と頸部へのハイパーサーミアを週に 1 回行った。なお,この動注療法は 持続動注ではなく，照射の時間のみに動注化学療法（bolus 投与）を連日同時に行うことが従来の動注 療法との大きく異なる点である。抗癌剤は CDDP $\left(5 \mathrm{mg} / \mathrm{m}^{2}\right)$ を連日投与, ドセタキセル (DOC： $\left.10 \mathrm{mg} / \mathrm{m}^{2}\right)$ 週 1 回投与し, ハイパーサーミアは RF 誘電外部加温法を用いて頸部に週に 1 回 50 分間行っ た。治療後に原発巣が $\mathrm{CR}$ なら原発は温存し, 頸部郭清術のみ施行した（Fig. 6C)。舌癌（T4N3M0） 症例（Figs. 7A and 7B）に対して HFT 法により両側の舌動脈（右側は顔面動脈との共通幹）にカテーテ ルを留置し, 舌原発巣と頸部リンパ節転移巣に造影剂の移行を確認後, 原発巣には IA-CRTを, 頸部リ
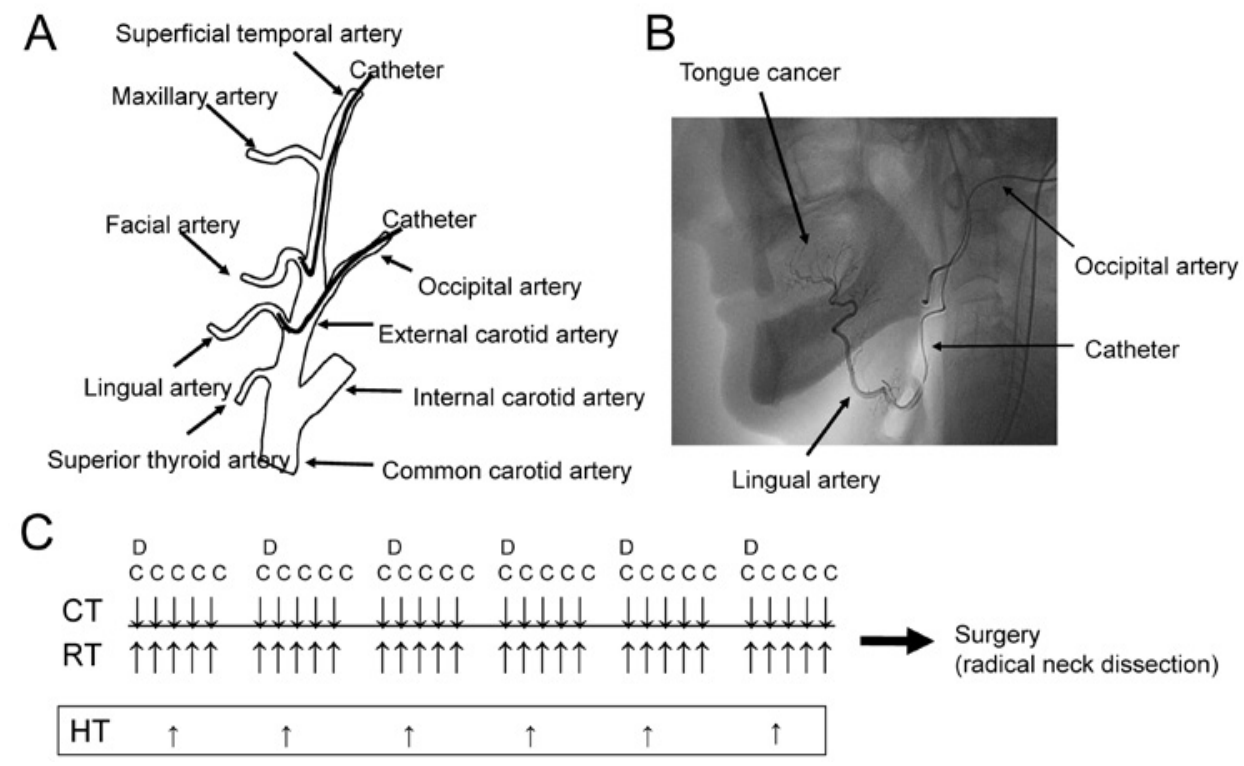

Fig. 6. A: Scheme of retrograde superselective intra-arterial infusion. B: Digital subtraction angiography (DSA) of the lingual artery using superselective intra-arterial infusion (HFT method). C: Schedule of preoperative combined therapy with retrograde superselective intra-arterial chemoradiotherapy (IA-CRT) and hyperthermia for cervical lymph node metastasis (N3). CT: Chemotherapy using intra-arterial infusion (bolus infusion during irradiation). D: Docetaxel $10 \mathrm{mg} / \mathrm{m}^{2} /$ week (Total: $60 \mathrm{mg} / \mathrm{m}^{2}$ ). C: Cisplatin $5 \mathrm{mg} / \mathrm{m}^{2} /$ day (Total: $150 \mathrm{mg} / \mathrm{m}^{2}$ ). RT: Radiotherapy $2 \mathrm{~Gy} /$ fraction (Total: $60 \mathrm{~Gy}$ ). HT: RF hyperthermia, 1 session/week (Total: 3-6 sessions). A and B: Adapted from Tohnai et al. ${ }^{32)}$. 
ンパ節転移巣には IA-CRT とハイパーサーミアの併用療法を行った（Figs.7C-E）。その後，下顎骨，皮 膚を含む腫瘍拡大切除術, 頸部郭清術を施行したが (Figs. $7 \mathrm{~F}$ and $7 \mathrm{G}$ ), 切除物の病理組織学的検討で は舌原発巣, 頸部リンパ節転移巣（N3）の全てにわたり生存可能な腫瘍細胞は認められなかった（Fig. $7 \mathrm{H})^{33)}$. 同様な治療を N3 症例の 9 例に対して行ったが, 切除病理学的検討では 9 例中 6 例の頸部リン パ節転移巣（N3）に腫瘍細胞を認めず（grade III 以上)，pCR 率も $66.7 \%$ と高い值であったままた局所 制御率も $85 \%, 5$ 年生存率も $51 \%$ と高い值であった（Fig. 8) ${ }^{35-37) . ~}$

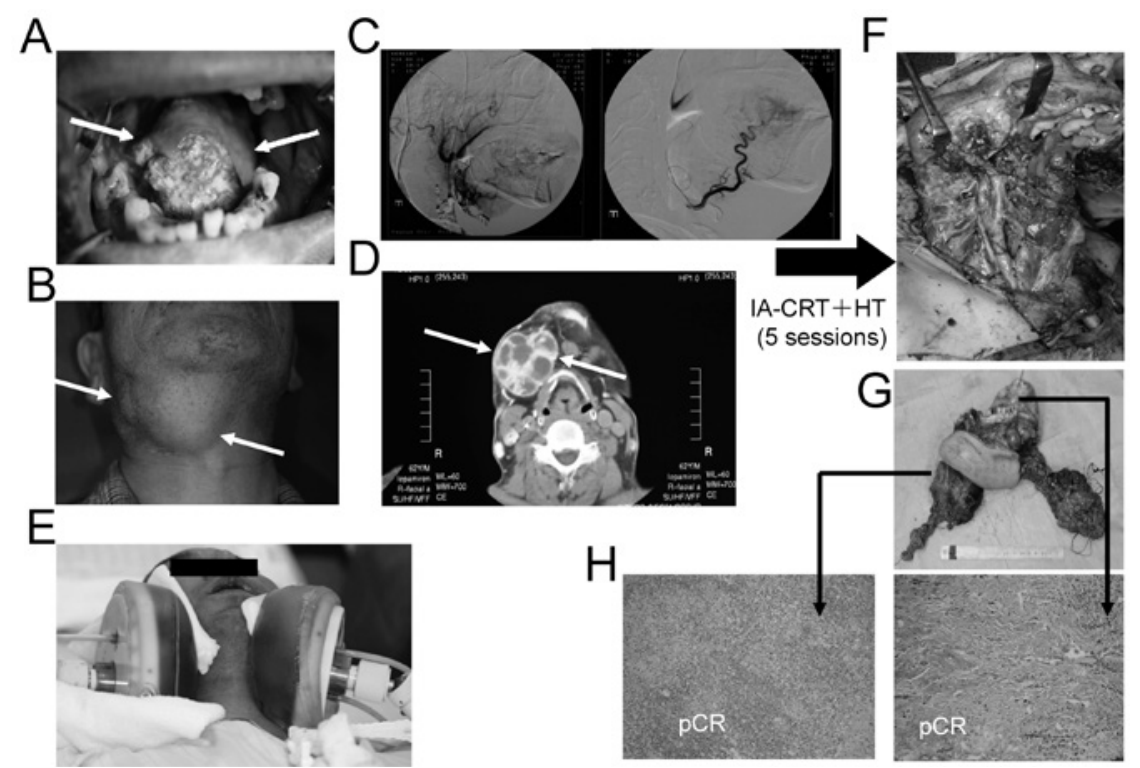

Fig. 7. A: Tongue cancer (T4N3M0); Intra oral finding before treatment. B: Cervical lymph node metastasis (N3). C: DSA of lingual artery and facial artery. D: CT-angio.; concentration of contrast medium to cervical lymph node metastasis (N3). E: RF hyperthermia for cervical lymph node metastasis (N3). F: Extended resection of tumor with radical neck dissection. G: Extraction of the tumor. H: Pathological finings of cervical lymph node metastasis (N3) and primary lesion of the tongue. Adapted from Tohnai et al. ${ }^{33)}$.

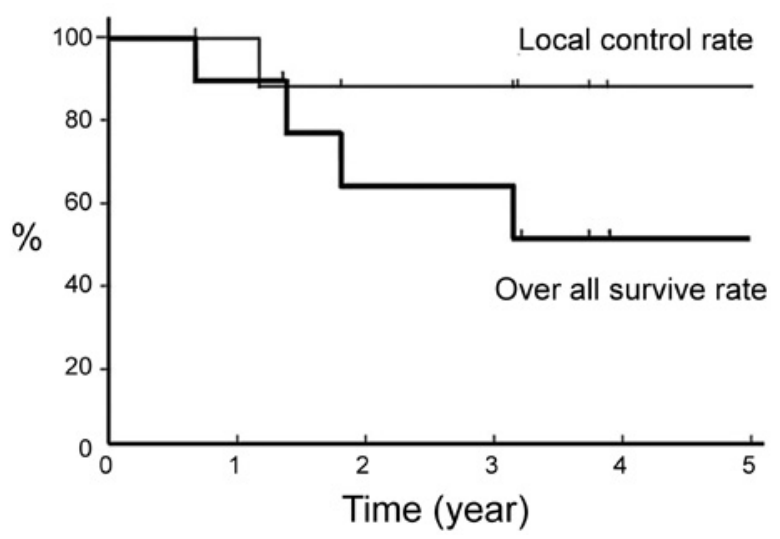

Fig. 8. Over all survive rate (thick line) and local control rate (thin line) of preoperative IA-CRT combined with hyperthermia for oral cancer with cervical lymph node metastasis (N3). Adapted from Mitsudo et al. ${ }^{35)}$. 


\section{2. 頸部リンパ節転移（N3）に対するIA-CRT とハイパーサーミアの併用療法（手術併用なし）}

次に，手術拒否例で原発巣も頸部リンパ節転移巣（N3）も全く手術せず，IA-CRT とハイパーサーミ アの併用療法のみの症例を供覧する。口底癌（T4aN3M0）(Figs. 9A a - c ) で両側顔面動脈にカテーテル を挿入し原発巣にIA-CRT を行い, 頸部リンパ節転移にはさらに, 5 回のハイパーサーミアの併用療法 を行った，治療後原発巣，頸部リンパ節転移ともにCRが得られた（Figs. 9Ad-f)。患者は手術拒否で2 年後に肺転移にて死亡したが，その時点でも原発部位，頸部リンパ節転移部位は CRのままで再発を認 めなかった ${ }^{38)}$. 舌癌 (T4N3M0) (Figs. 9B a-c) に対して両側舌動脈, 両側顔面動脈にカテーテルを挿入し, 原発巣にIA-CRT を，また頸部リンパ節転移（N3）にIA-CRT とハイパーサーミア（6回）の併用療法 を行い手術拒否にて経過観察しているが，7年後も再発を認めず，経過良好である (Figs. 9B $d-f)^{399}$.

A
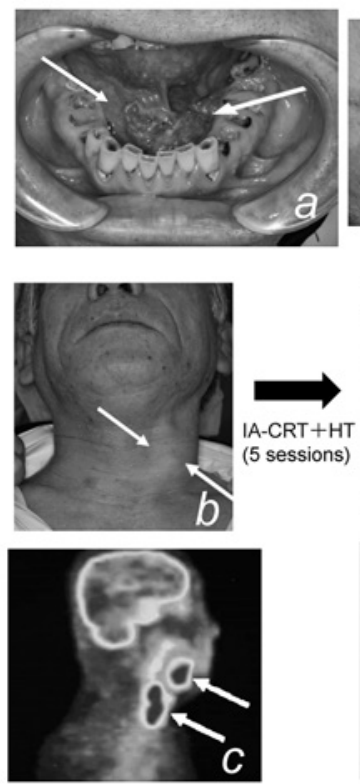
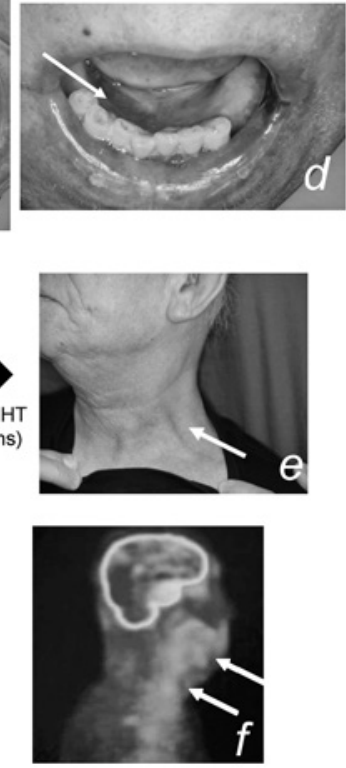

B
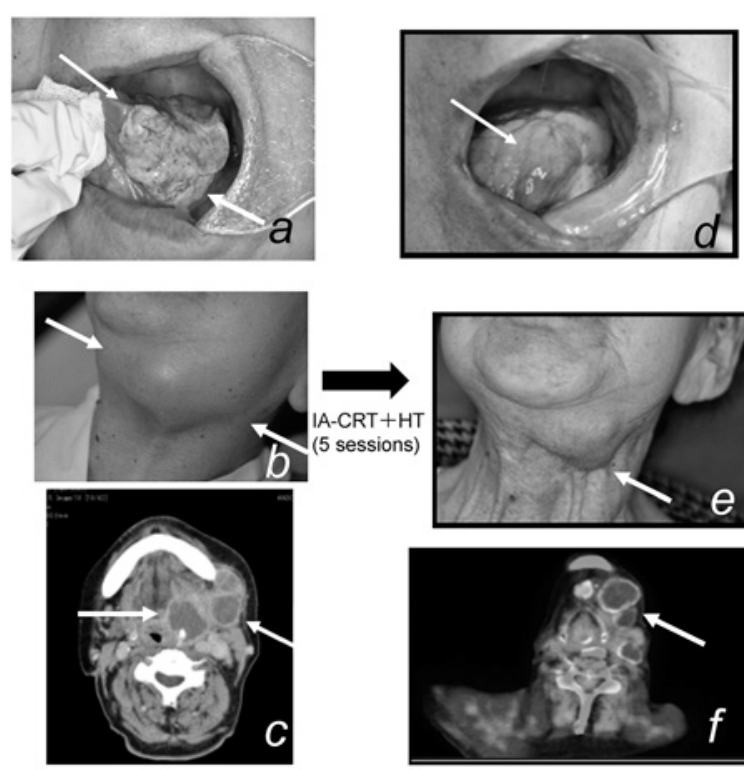

Fig. 9. A: Oral floor cancer $(\mathrm{T} 3 \mathrm{~N} 3 \mathrm{M} 0)^{38)}$. $\boldsymbol{a}$ : Intra oral finding before treatment. $\boldsymbol{b}$ : Cervical lymph node metastasis (N3). $\boldsymbol{c}$ : PET finding. $\boldsymbol{d}$ : Intra oral finding in 2 years after IA-CRT combined with hyperthermia. $\boldsymbol{e}$ : Cervical finding in 2 years after IA-CRT combined with hyperthermia. f: PET finding in 2 years after IA-CRT combined with hyperthermia. B: Tongue cancer $(\mathrm{T} 4 \mathrm{~N} 3 \mathrm{M} 0)^{39)}$. $\boldsymbol{a}$ : Intra oral finding before treatment. $\boldsymbol{b}$ : Cervical lymph node metastasis (N3). $\boldsymbol{c}$ : CT finding of cervical lymph node metastasis (N3). $\boldsymbol{d}$ : Intra oral finding in 7 years after IA-CRT combined with hyperthermia. $\boldsymbol{e}$ : Cervical finding in 7 years after IA-CRT combined with hyperthermia. $f$ : PET finding in 7 years after IA-CRT combined with hyperthermia. A: Adapted from Shibasaki et al. ${ }^{38)}$, B: Adapted from Nishiguchi et $a{ }^{39}{ }^{39}$.

\section{5. 結語}

口腔癌に対しては現在手術が中心的な治療方法であるが, 進展口腔癌に対しては術後の機能障害（構 音障害，咀嚼障害，嚥下障害)，審美障害が大きな問題である。この問題を解決する治療法の一つにハ イパーサーミアの占める位置は大きいものと思われた．特に，IA-CRT とハイパーサーミアの併用療法 は進行口腔癌の頸部リンパ節転移（N3）にも極めて有効であった，また，将来的には放射線療法も化 学療法も使用せず, 磁性微粒子を超選択的動注法にて腫痬栄養血管へ注入し, 交流磁場下でのハイ パーサーミアのみで腫瘍の消滅が得られるかもしれない. 


\section{6. 謝辞}

この論文は平成 26 年第 1 回日本ハイパーサーミア学会の学会賞の受賞講演の一部を論文にしたもの である，受賞するにあたり日本ハイパーサーミア学会前理事長の大西武雄先生を初め関係各位の諸先生 方に心より厚く御礼申し上げます。また，この研究は下記の各方面の先生方の温かいご指導とご協力を 頂いたものであり，ここに心より梁く感謝申し上げます。

小林達也 先生 (名古屋共立病院 名古屋放射線外科センターセンター長)

大塚健三 先生（中部大学応用生物学 教授）

小林 猛 先生 (名古屋大学 名誉教授)

不破信和 先生（伊勢赤十字病院第 1 放射線科 部長）

石川義弘 先生（横浜市立大学大学院医学研究科循環器制御学 教授）

後藤康之 先生（せこ歯科クリニック院長）

林 康司 先生 (名古屋第二赤十字病院歯科口腔外科 部長)

光藤健司 先生 (横浜市立大学大学院医学研究科顎顔面口腔機能制御学 准教授)

兼子隆二 先生（豊田厚生病院歯科口腔外科 部長）

服部浩朋 先生 (名城病院歯科口腔外科 部長)

西口浩明 先生 (海南病院歯科口腔外科 部長)

山田健久 先生（勝川オーラルクリニック 院長）

山根光雄 先生 (山根歯科矯正歯科 院長)

杉戸一博 先生 (清水山歯科医院 院長)

森 俊彰先生（もり歯科クリニック院長）

松野秀幸 先生（M デンタルクリニック松野歯科 院長）

山本憲幸 先生 (名古屋大学大学院医学系研究科顎顔面外科学 講師)

福井敬文 先生（ふくい歯科クリニック 院長）

浜口重朗 先生 (ミッドランドスワン歯科・矯正歯科 院長)

松本行史 先生 (西知多総合病院歯科口腔外科 部長)

小泉俊之 先生（横浜市立大学大学院医学研究科顎顔面口腔機能制御学 講師）

飯田昌樹 先生（横浜市立大学大学院医学研究科顎顔面口腔機能制御学 助教）

佐藤 格 先生（横浜市立大学大学院医学研究科循環器制御学 助教）

\section{引用文献}

1) Hayashi Y., Tohnai I., Kaneda T., Kobayashi T., Ohtsuka K.: Translocation of hsp-70 and protein synthesis during continuous heating at mild temperatures in HeLa cells. Radiat Res, 125: 80-88, 1991.

2) Liu Y.C., Hayashi Y., Tohnai I., Kaneda T., Ohtsuka K.: Effects of continuous heating at mild temperatures on the translocation of hsp70 and protein synthesis in NRK cells. J Radiat Res, 33: 199-210, 1992.

3) Hattori H., Liu M.C., Tohnai I., Ueda M., Kaneda T., Kobayashi T., Tanabe K., Ohtsuka K.: Intracellular localization and partial amino acid sequence of a stress-inducible 40-kDa protein in HeLa cells. Cell Struct Funct, 17: 77-89, 1992.

4) Sugito K., Yamane M., Hattori H., Hayashi Y., Tohnai I., Ueda M., Tsuchida N., Ohtsuka K.: Interaction between hsp70 and hsp40, eukaryotic homologues of DnaK and DnaJ, in human cells expressing mutant-type p53. FEBS Lett, 358: 161-164, 1995.

5) Kaneko R., Hattori H., Hayashi Y., Tohnai I., Ueda M., Ohtsuka K.: Heat-Shock protein 40, a novel predictor of 
thermotolerance in murine cells. Radiat Res, 142: 91-97, 1995.

6) Yamane M., Hattori H., Sugito K., Hayashi Y., Tohnai I., Ueda M., Nishizawa K., Ohtsuka K.: Cotranslocation and colocalization of hsp40 (DnaJ) with hsp70 (DnaK) in mammalian cells. Cell Struct Funct, 20: 157-166, 1995.

7) Mitsudo K., Kobayashi M., Tohnai I., Ueda M., Kotani H., Hoshino T.: Electron-microscopic and immunohistochemical studies of Langerhans cells and Thy-1 positive cells in mouse tongue epithelium subjected to local hyperthermia. Arch Oral Biol, 40: 533-538, 1995.

8) Kaneko R., Hayashi Y., Tohnai I., Ueda M., Ohtuka K.: Hsp40, a possible indicator for thermotolerance of murine tumor in vivo. Int J Hyperthermia, 13: 507-516, 1997.

9) Yamada T., Ito M., Hayashi Y., Tohnai I., Ueda M.: Effect of combined local OK-431 injection and hyperthermia on SCC tumors in mice. J Radiat Res, 39: 101-109, 1998.

10) Mori T., Sugito K., Hata M., Tohnai I., Hayashi Y., Ueda M., Ohtsuka K.: Mammalian hsp70 and 40: Characteristics induction by environmental stress and tissue specific expression. Jpn J Hyperthermic Oncol, 15: 21-30, 1999.

11) Matsumoto K., Yamamoto N., Hagiwara S., Saito M., Furue H., Shigetomi T., Narita Y., Mitsudo K., Tohnai I., Kobayashi T., Ueda M.: Optimization of hyperthermia and dendritic cell immunotherapy for squamous cell carcinoma. Oncol Rep, 25: 1525-1532, 2011.

12) Kobayashi T., Kida Y., Tanaka T., Kageyama N., Kobayashi H., Amemiya Y.: Magnetic induction hyperthermia for brain tumor using ferromagnetic implant with low Curie temperature. I. Experimental study. J Neurooncol, 4: 175-181, 1986.

13) Kobayashi T., Tanaka T., Kida Y., Matsui M., Ikeda T.: Interstitial hyperthermia of experimental brain tumor using implant heating system. J Neurooncol, 7: 201-208, 1989.

14）後藤康之, 藤内祝, 林康司, 金田敏郎, 木田義久, 小林達也, 松井正顕.: Implant Heating System による口腔悪性腫瘍に対 する組織内温熱療法 一家兔腫瘍モデルによる検討一. Jpn J Hyperthermic Oncol, 6: 439-449, 1990.

15) 後藤康之, 藤内祝, 金田敏郎, 伊藤雅文, 浅井淳平.: 口腔悪性腫瘍に対する Implant Heating System を用いた組織内温 熱療法の実験的研究 一家兔 VX7 移植舌腫瘍モデルにおける病理組織学的検討一. 日本口腔科学会雑誌, 40: 778-788, 1991.

16) 藤内祝, 後藤康之, 林康司, 金田敏郎, 木田義久, 小林達也, 松井正顕.: 舌癌にする Implant Heating Systemによる組織内温 熱療法. Jpn J Hyperthermic Oncol, 6: 450-461, 1990.

17）藤内祝, 後藤康之, 林康司, 金田敏郎, 小林達也.: 頭頸部癌に対する発熱磁性体を用いた Implant Heating System の効果 と適応について. 日本頭頸部腫瘍学会誌, 17: 156-161, 1991.

18) 藤内祝, 林康司, 上田実, 小林達也, 松井正顯.: 口腔癌に対する Implant Heating System(IHS) を用いた温熱化学療法の効 果と適応. Jpn J Hyperthermic Oncol, 11: 76-85, 1995.

19) Tohnai I., Goto Y., Hayashi Y., Ueda M., Kobayashi T., Matsui M.: Preoperative thermochemotherapy of oral cancer using magnetic induction hyperthermia (Implant Heating System: IHS). Int J Hyperthermia, 12: 37-48, 1996.

20) Tohnai I., Hayashi Y., Mitsudo K., Kobayashi T., Matsui M., Ueda M.: Thermochemotherapy of using magnetic induction hyperthermia (Implant Heating System: IHS) for cancer of the tongue. Nagoya J Med Sci, 59: 49-54, 1996.

21) Tohnai I., Hattori H., Hayashi Y., Tsurusako S., Niimi A., Ueda M.: Malignant fibrous histiocytoma of the mandible treated by thermoradiotherapy. Hosp Dent Oral Maxillofac Surg, 7: 52-54, 1995.

22) Matsuno H., Tohnai I., Mitsudo K., Hayashi Y., Ito M., Shinkai M., Kobayashi T., Yoshida J., Ueda M.: Intestitial hyperthermia using magnetite cationic liposomes inhibit to tumor growth of VX-7 transplanted tumor in rabbit tongue. Jpn J Hyperthermic Oncol, 17: 17-26, 2001.

23) Hamaguchi S., Tohnai I., Ito A., Mitsudo K., Shigetomi T., Ito M., Honda H., Kobayashi T., Ueda M.: Selective hyperthermia using magnetoliposomes to target cervical lymph node metastasis in a rabbit tongue tumor model. Cancer Sci, 94: 834-839, 2003. 
24) Sato I., Umemura M., Mitsudo K., Kioi M., Nakashima H., Iwai T., Feng Xianfeng., Oda K., Miyajima A., Makino A., Iwa M., Eguchi H., Ishikawa Y., Tohnai I.: Hyperthermia generated with ferucarbotran (Resovist ${ }^{\circledR}$ ) in an alternating magnetic field enhances cisplatin-induced apoptosis of cultured human oral cancer cells. J Physiol Sci, 64: 177-183, 2014.

25) Sato I., Umemura M., Mitsudo K., Fukumura H., Kim J., Hoshino Y., Nakashima H., Kioi M., Nakakaji R., Sato M., Fujita T., Yokoyama U., Okumura S., Oshiro H., Eguchi H., Tohnai I., Ishikawa Y.: Simultaneous hyperthermia-chemotherapy with controlled drug delivery using single-drug nanoparticle. Sci Rep, 6: 24629, 2016.

26) Hayashi Y., Matsuno H., Tohnai I., Ueda M., Murano T., Yamada T.: Effectiveness of hyperthermia for head and neck advanced malignant tumors. Asian J Oral Maxillofac Surg, 9: 11-17, 1997.

27) 中井英貴, 林康司, 光藤健司, 藤内祝, 上田実.: 煩部に再発した骨肉腫に対する温熱療法の臨床効果. 日本口腔科学会雑 誌, 44: 207-211, 1995.

28) 都丸泰寿, 林康司, 粕谷幸生, 兼子隆次, 藤内祝, 上田実.: 悪性エナメル上皮腫進展例に対する温熱放射線併用療法の応 用. 日本口腔外科学会雑誌, 43: 185-187, 1997.

29) Tohnai I., Hayashi Y., Mitsudo K., Shigetomi T., Ueda M., Ishigaki T.: Prognostic evaluation of preoperative thermochemoradiotherapy for N3 cervical lymph node metastases of oral cancer. Oncology, 62: 234-240, 2002.

30) Tohnai I., Fuwa N., Hayashi Y., Kaneko R., Tomaru Y., Hibino Y., Ueda M.: New superselective intra-arterial infusion via superficial temporal artery for cancer of the tongue and tumor tissue platinum concentration after carboplatin (CBDCA) infusion. Oral Oncol, 34: 387-390, 1998.

31) 藤内祝, 不破信和, 光藤健司, 古谷和久, 福井敬文, 山本憲幸, 西口浩明.: 口腔癌に対する浅側頭動脈よりの新しい超選択 的動注法一湾曲カテーテルと PU カテーテルを用いた方法一. 頭頸部腫瘍, 31: 39-44, 2005.

32) 藤内祝.: 口腔癌に対する超選択的動注化学療法一臓器温存治療を目指して一. 日口外誌, 61: 86-101, 2015.

33) 藤内祝, 光藤健司, 藤本保志, 伊藤善之, 齋藤清, 亀井讓, 不破信和, 佃守.: 超進行癌の治療はどこまでするか一逆行性超 選択的動注化学療法を中心に一. 頭頸部癌, 36: 428-435, 2010.

34) 光永幸代, 光藤健司, 岩井俊憲, 矢島康治, 柴崎麻衣子, 大屋貴志, 大原良仁, 廣田誠, 藤内祝.: 温熱療法を併用した逆行性 超選択的動注化学放射線療法が著効した上顎歯肉癌 N3 の 1 例. 口腔腫瘍, 22: 157-163, 2010.

35) Mitsudo K., Koizumi T., Iida M., Iwai T., Oguri S., Yamamoto N., Itoh Y., Kioi M., Hirota M., Tohnai I.: Thermochemoradiation therapy using superselective intra-arterial infusion via superficial temporal and occipital arteries for oral cancer with N3 cervical lymph node metastases. Int J Radiat Oncol Biol Phys, 83: e639-e645, 2012.

36) Mitsudo K., Tohnai I.: Oral cancer -Combination therapy with hyperthermia and chemoradiotherapy-. Hyperthermic Oncology from Bench to Bedside, Kokura S, Yoshikawa T, Ohnishi T, Eds., Springer- Singapore, Singapore, pp.177-191, 2016.

37) Mitsudo K., Tohnai I.: Cemoradiotherapy using intra-arterial infusion. Oral Cancer: Diagnosis and Therapy. Kirita T., Omura K. Eds., Springer-Japan, Tokyo, pp.319-333, 2015.

38) 柴崎麻衣子, 光藤健司, 岩井俊憲, 矢島康治, 大屋貴志, 大原良仁, 光永幸代, 廣田誠, 藤内祝.: 口底癌 (T4aN3M0)に対し て温熱化学放射線療法が著効した 1 例. 口腔腫瘍, 23: 9-15, 2011.

39) Nishiguchi H., Mitsudo K., Yamamoto N., Tohnai I.: Thermochemoradiotherapy using superselective intra-arterial infusion for N3 cervical lymph node metastases of tongue cancer. J Cancer Res Ther, 9: 718-720, 2013. 